\title{
TOYS IN TECHNICAL AREA OF EDUCATION IN KINDERGARTENS
}

\section{Miroslav JANU}

Abstract: The contribution is dealing with the problems of preschool education, mainly in the technical area of the education of teachers in kindergartens. It searches the possibilities of enhancing the qualities of present university education within the technical subjects in pedagogical preparations of the alumni studying to be a teacher in a kindergarten.

The usage of a game and a toy appears as one of the most effective means of preschool education even in the technical area of education.

Key words: toys, technical education, kindergarten.

\section{HRAČKY V TECHNICKÉ OBLASTI VZDĚLÁVÁNÍ PRO MATEŘSKÉ ŠKOLY}

Resumé: Příspěvek se zabývá problematikou předškolní výchovy především $\mathrm{v}$ technické oblasti vzdělávání učitelů mateřských škol. Hledá možnosti zkvalitnění současné vysokoškolské výuky $\mathrm{v}$ rámci předmětů technického charakteru $\mathrm{v}$ pedagogické př́pravě absolventů oboru Učitelství pro mateřské školy. Vychází z potřeb utvářet klíčové kompetence zaměřené zejména na rozvoj osobnosti a na výchovu občana schopného úspěšné adaptability v budoucí životní praxi. Jedním z nejúčinnějších prostředků takové předškolní výchovy se jeví využití hry a hračky, a to i v technické oblasti vzdělávání.

Klíčová slova: hračky, technická výchova, mateřská škola.

\section{1 Úvod}

Předměty

technického v pedagogické prŕípravě učitelů rozś́hlou problematiku postavení techniky využití technických realizací $\mathrm{k}$ rozvoji společnosti a jejího pozitivního civilizačního vývoje. Výstupy a cíle vyučovacích předmětů směřují proto zejména $\mathrm{k}$ jejich aplikaci do pedagogické i občanské praxe včetně předškolní oblasti.

\section{Obecná východiska výuky předmětů} technického charakteru

Výukové disciplíny předmětů technického charakteru zahrnují teoretické poznatky i praktické dovednosti a jsou koncipovány v duchu uživatelského pojetí techniky a s cílem bezprostředně pozitivně ovlivňovat občanský život člověka.

Studentům vysokoškolského studia a jejich prostřednictvím i nejmladším předškolním dětem nabízejí co nejširší paletu činností. Rozšiřrování intelektových, technických, motorických, kreativních aj. podnětů vede nejen $\mathrm{k}$ tomu, aby se mohli individuálně projevit, ale aby bylo možné také jejich žádoucí technické tvưrčí předpoklady již od útlého věku dále účinně rozvíjet.

\section{Předměty technického charakteru $v$ celku a koncepci vzdělávání}

Všechny výše uvedené okolnosti výuky vycházejí z humanistické koncepce vzdělávání a tvoří ucelený systém. Nejbližší návaznosti se projevují v těsném sepětí s intencemi současné informační společnosti. Přehlédnout nelze ani prosperující inspiraci v oblasti multikulturní a ekologické výchovy, výtvarné výchovy, jazykové výchovy, matematiky, etiky aj. Specifické vazby tvoří předpoklad seznámení se s obsahem a cíli pedagogické práce, které jsou podstatnou složkou vzdělávání v navazující výuce na 1. stupni základních škol.

Předměty technického charakteru $\mathrm{v}$ takto chápaném celku potom plní v pedagogické i společenské praxi řadu dalších funkcí - např̀. výchovnou, vzdělávací, kulturní, regenerační a relaxační, sociální, preventivní aj. Vedou k seberealizaci a sebepoznávání, objevování vlastních schopností a jejich rozvíjení. Tím se významným způsobem podílejí na sledované prrirozené kultivaci osobnosti, na rozvoji talentů a vytváření nových sociálních vztahů a vazeb včetně důrazu na flexibilní uplatnění v prostředí současné IT společnosti. 


\section{Předškolní vzdělávání}

Předškolní vzdělávání tvoří integrální součást dnešního vzdělávacího systému. Usiluje nejen o rozvoj osobnosti jedince, ale vychází především z potřeby, připravit dítě na vstup do školního prostředí a usnadnit mu tak úspěšné začlenění do primárního vzdělávání. Za výchovu a vzdělávání dětí sice odpovídají především rodiče a oni jsou také prvními nositeli poznání, ale ne vždy a všude se jim daří zajistit komplexnost tohoto působení.

Vzhledem $\mathrm{k}$ tomu, že první roky života ovlivňují do značné míry rozvoj psychických a somatických předpokladů i sociálních postojů dětí a mají klíčový význam pro utváření jejich osobnosti, je předškolní úroveň vzdělávání rozhodujícím podnětem pro stanovení jeho obsahu a dosažitelných cílů.

Předškolní vzdělávání $\mathrm{v}$ současném pojetî podporuje výchovné působení rodiny, doplňuje je o specifické oblasti, rozvíjí je a obohacuje. Děti získávají především sociální zkušenosti, základní poznatky o předmětném světě a životě kolem sebe a také první podněty pro získání zájmu o pokračující vzdělávání a celoživotní učení.

\section{Hry a hračky}

Analýza názorů ze současné společenské i pedagogické praxe potvrzuje význam hračky pro zdravý vývoj dítěte. Hračka jako fenomén dětství (ale někdy i v dospělosti) je nenahraditelná pro svoje specifické možnosti využití. Funguje především jako jeden z významných přirozených prvků mentálních impulsů pro rozvíjení individuality a osobnosti jedince.

Činnostní a dovednostní prvky hry umožňují realizovat takovou manipulaci s hračkou, která vede $\mathrm{k}$ rozvoji motorických schopností, smyslových vlastností a tím k celkovému rozvoji intelektové i emoční sféry osobnosti a usnadňuje také realizaci sociální integrace dětí. Primární podstatou využití her a hraček pro předškolní vzdělávání je proto především jejich komunikativní a sociální rozměr.

Podceňovat nelze ani tradiční historické zkušenosti a lidovou tvorbu, utvářející podmínky pro zachování kontinuální vývojové linie v procesu mezigeneračního sdílení kulturních hodnot a pochopení civilizačních a multikulturních souvislostí.

V současnosti dostupné klasické i nově vytvořené soubory hraček (př́padně i didaktických pomůcek herního charakteru) mají velmi různorodou úroveň. $\mathrm{Na}$ běžném trhu, zdá se bohužel, že spíše převládá zájem výrobců o hračku jako zboží, jež se př́liš neřídí pedagogickými, didaktickými, ba ani zdravotnickými zřeteli a preferuje výrobu hraček s minimálním vzdělávacím, výchovným a estetickým zřetelem, se zaměřením zejména na ekonomický efekt.

\section{Hry a hračky $v$ technické oblasti vysokoškolského vzdělávání pro mateřské školy}

Poznatky o významu a působení her a hraček na rozvoj dítěte se stávají inspirací pro inovační pedagogické tendence a úsilí o zkvalitnění př̀edškolní výchovy i v technické oblasti vzdělávání učitelů mateřských škol. Nejvýznamnější možností se jeví aktualizace současné vysokoškolské výuky v rámci předmětů technického charakteru v pedagogické přípravě absolventů oboru Učitelství pro mateřské školy, preferujících utváření klíčových kompetencí zaměřených na rozvoj osobnosti a na výchovu dítěte $\mathrm{v}$ občana schopného flexibilní adaptability v budoucí životní praxi.

Zhodnocení analýzy koncepce, obsahu a výsledků dosavadní vysokoškolské výuky poukazují na primární nutnost zvýšení vzdělanosti a informovanosti učitelů mateřských škol v této oblasti.

\section{Hry a hračky $v$ předmětech technického charakteru pro předškolní vzdělávání}

Problematika her a hraček nebyla dosud samostatně sledovaným tématem výuky predškolní výchovy $v$ rámci předmětů technického charakteru. Je proto třeba $\mathrm{v}$ tomto smyslu rozšířit sylaby a hledat optimální zařazení této problematiky do výuky. Interdisciplinární charakter výuky technické a informační výchovy začlenění těchto inovačních prvků zvláště vhodně umožňuje.

V praxi to znamená přepracovat sylaby výuky na VS̆ se zřetelem k širším souvislostem techniky a hmotné kultury a s dưrazem na jejich poslání při tvorbě životního prostředí, včetně důrazu na komunikativní a sociální význam vzdělání a výchovy.

\subsection{V oblasti inovovaného zařazení problematiky hraček}

V oblasti inovovaného zařazení problematiky hraček do vysokoškolské výuky učitelů mateřských škol se jeví jako nejvhodnější vycházet z kriterií stanovených mezinárodní organizací ICCP - International Council for 
Children's Play (založené již 1959 v Ulmu). V těchto kriteriích jsou obsažena hlediska vědních disciplín zabývajících se hrou a hračkou, stejně jako hlediska a požadavky praktických oborů, které se hračkou zabývají.

Jsou to napřr. :

věk dítěte, pro který jsou hračky určeny, využití dětské fantazie při hře, četnost hravých možností (čím více možností hračka poskytuje, tím je pro dítě zajímavější a tím větší má rozvíjející hodnotu, jednorázová hračka brzy vyvolává nezájem a pasivitu), srozumitelnost hračky (výraz a tvarové řešení), velikost hračky (viz i manipulaci s menšími prvky), množství a skladba hraček (většinou nahodilý výběr hraček $\mathrm{v}$ rodinách, řízený výběr v mateřských školách), vhodnost materiálu (měl by odpovídat uměleckému i pedagogickému účelu hračky, její funkci a konstrukci), tvar a barva hračky (jsou určující pro přijetí hračky dítětem; dítě většinou preferuje jasné barvy, příp. jsou optimální světle hnědé odstíny - prŕírodní dřevo - doplněné plochami jasných sytých barev - bílá, žlutá, červená; barva nemusí souhlasit s realitou), pevnost a trvanlivost hračky, konstrukce a mechanika (i vzhledem $\mathrm{k}$ použitému materiálu i k nízkému věku dítěte), bezpečnost hračky (nejedovatost nátěrů, odolnost vǔči slinám a potu, nehořlavost, hygieničnost, bezpečná velikost hračky a jejich dílů, zaoblenost apod.), cena hračky aj. (1).

\subsection{Návrh úpravy studijních programů}

Důraz je kladen zejména na tyto optimální složky:vědomostní a činnostní kompetence, dovednostní kompetence, problematiku hry a hračky (viz výše), bezpečnost výuky.

Návrhy a studie hraček, zhotovované jako součást výuky, budou tvořeny také $\mathrm{v}$ intencích nejnovějších designérských poznatků.

Realizace zahrnuje zejména tematické okruhy:

- základní vědomosti o materiálech,

- základní poznatky o nástrojích a pracovních pomůckách,

- základní poučení o pracovních postupech a technologiích,

- hygienická a bezpečnostní pravidla,

- organizační systém pracovního procesu,

- kreativní přístup k pracovním činnostem,

- rozvoj motorických a kombinačních prvků,

- civilizační a kulturní fenomén techniky,

- ekologické aspekty techniky,

- uživatelské aspekty techniky, prostředí,

technika jako součást životního prostředí,

kultura bydlení a odívání, utváření

- současné možnosti designerské práce s PC.

S utvářením vědomostních a činnostních předpokladů úzce souvisejí kompetence dovednostní. V některých okruzích se dovednostní znalosti stávají prostředkem k získání základních vědomostí a pojmů (viz např. vlastnosti materiálů, bezpečnost práce, organizace pracovního procesu, uživatelské aspekty techniky, tvorba životního prostředí ap.). Základní důraz je kladen na motorickou oblast a vytváření základních pracovních dovedností prostřednictvím praktických činností.

Dovednostní složku procesu vzdělávání preferují zejména tyto výukové okruhy:

- manipulace $\mathrm{s}$ nástroji $\mathrm{i}$ nářadím a pracovními pomůckami, výběr nástrojů a materiálů podle vhodnosti použití, poznávání vlastností materiálů a jejich srovnávání,

- zpracování vybraných materiálů a experimentování s nimi: práce s papírem a kartónem, práce s textilem, práce se dřevem, práce $\mathrm{s}$ kovem, práce $\mathrm{s}$ modelovací hmotou, práce s plasty aj.,

- práce s drobným materiálem,

- $\quad$ práce se stavebnicemi.

\section{Závěr}

Nově odborně a společensky akceptovaná a kurikulárně podchycená problematika využití herního potenciálu a tvorby hraček je významnou inspirací pro tvưrčí přístupy $\mathrm{k}$ realizaci flexibilní koncepce a inovace výuky pro předškolní vzdělávání také $\mathrm{v}$ předmětech technického charakteru.

\section{Literatura}

[1] JANU, M. Dřevěná hračka a její využití při výchově handicapovaných dětí. Disertační práce. Olomouc: UP, 2001.

Lektoroval: Doc. PhDr. Libuše Podlahová, Dr.

Miroslav Janu, RNDr.,PhDr.,

Katedra technické a informační výchovy, PdF UP, Žižkovo nám. 5, 77140 Olomouc,

ČR,

tel. 00420585635804 , e-mail:janu@pdfnw.upol.cz 